University of New Hampshire

University of New Hampshire Scholars' Repository

$12-2000$

\title{
Palaeoecological Implications of Archaeological Seal Bone Assemblages: Case Studies from Labrador and Baffin Island
}

James M. Woollett

Bowdoin College

Anne S. Henshaw

Bowdoin College

Cameron P. Wake

University of New Hampshire - Main Campus, cameron.wake@unh.edu

Follow this and additional works at: https://scholars.unh.edu/earthsci_facpub

\section{Recommended Citation}

Woollett, JM, AS Henshaw, CP Wake (2000) Palaeoecological Implications of Archaeological Seal Bone Assemblages: Case Studies from Labrador and Baffin Island. Arctic 53(4), 395-413.

This Article is brought to you for free and open access by the Earth Sciences at University of New Hampshire Scholars' Repository. It has been accepted for inclusion in Earth Sciences Scholarship by an authorized administrator of University of New Hampshire Scholars' Repository. For more information, please contact Scholarly.Communication@unh.edu. 


\title{
Palaeoecological Implications of Archaeological Seal Bone Assemblages: Case Studies from Labrador and Baffin Island
}

\author{
JAMES M. WOOLLETT, ${ }^{1}$ ANNE S. HENSHAW ${ }^{2}$ and CAMERON P. WAKE ${ }^{3}$
}

(Received 7 April 1999; accepted in revised form 15 September 2000)

\begin{abstract}
In recent years, increasing scientific attention has been paid to sea mammals as biological indicators of Arctic environmental change. The usefulness of animals such as ringed seal (Phoca hispida), harp seal (Phoca groenlandica), bearded seal (Erignathus barbatus), and harbour seal (Phoca vitulina) as indicator species is due to the close relationship of their range, reproductive cycles, and life histories to sea ice. The behaviour and distribution of these species correlate with ice conditions in the areas where the animals are encountered. The proportions of seal species represented in archaeological deposits may therefore reflect, at least in part, environmental conditions characterizing past seascapes.

This paper examines zooarchaeological data from several Thule and historic Inuit archaeological sites in Baffin Island and Labrador, sites occupied during the last 700 years, to determine whether regional relationships can be demonstrated between subsistence economies, seal populations, and sea ice conditions. Ratios of ringed seal, harbour seal, bearded seal, and walrus (Odobenus rosmarus) bone frequencies from several archaeological sites are analyzed and discussed in light of new highresolution proxy sea ice and regional palaeoenvironmental data. This exploratory study suggests that characteristics in seal species composition reflected in these assemblages can, in some circumstances, be correlated with recent sea ice reconstructions. However, a regional comparison of a larger number of more precisely dated archaeological sites is required for a full examination of these relationships.
\end{abstract}

Key words: bearded seals, Frobisher Bay, Hamilton Inlet, harbour seals, indicator species, palaeoecology, Penny Ice Cap, polynyas, ringed seals, sea ice, zooarchaeology

RÉSUMÉ. Au cours des dernières années, on a porté de plus en plus d'attention scientifique aux mammifères marins en tant qu'indicateurs biologiques du changement global dans l'Arctique. L'utilité d'animaux tels que le phoque annelé (Phoca hispida), le phoque du Groenland (Phoca groenlandica), le phoque barbu (Erignathus barbatus) et le phoque commun (Phoca vitulina) comme espèces indicatrices est due au rapport étroit que leurs aires de distribution, leurs cycles de reproduction et leurs cycles de vie ont avec la glace marine. Le comportement et la distribution de ces espèces sont corrélés avec les conditions de la glace dans les zones où l'on rencontre ces animaux. Les proportions des espèces de phoques qui se trouvent dans les dépôts archéologiques pourraient donc refléter, du moins partiellement, les conditions environnementales qui caractérisaient les paysages marins du passé.

Cet article se penche sur les données zooarchéologiques provenant de plusieurs sites archéologiques Thulé et inuits dans l'île Baffin et le Labrador, sites occupés au cours des 700 dernières années, pour déterminer si l'on peut démontrer l'existence de rapports régionaux entre les économies de subsistance, les populations de phoques et les conditions de glace marine. Des taux de fréquence d'os de phoque annelé, de phoque commun, de phoque barbu et de morse provenant de plusieurs sites archéologiques font l'objet d'une analyse et d'une discussion à la lumière de nouvelles données indirectes à haute résolution sur la glace marine et sur le paléoenvironnement régional. Cette étude préliminaire suggère que les caractéristiques présentes dans la composition des espèces de phoques reflétée dans ces assemblages peuvent, dans certaines conditions, être corrélées aux reconstructions récentes de la glace marine. Une comparaison régionale d'un plus grand nombre de sites archéologiques datés de façon plus précise est toutefois nécessaire pour un examen exhaustif de ces rapports.

Mots clés: phoque barbu, baie Frobisher, Hamilton Inlet, phoque commun, espèce indicatrice, paléoécologie, calotte glaciaire Penny, polynie, phoque annelé, glace marine, zooarchéologie

Traduit pour la revue Arctic par Nésida Loyer.

\footnotetext{
${ }^{1}$ The Peary-MacMillan Arctic Museum and Arctic Studies Center, Bowdoin College, 9500 College Station, Brunswick, Maine 040118495, U.S.A.; jwoollet@bowdoin.edu

${ }^{2}$ Coastal Studies Center, Bowdoin College, 9500 College Station, Brunswick, Maine 04011-8495, U.S.A.; ahenshaw @bowdoin.edu

${ }^{3}$ Climate Change Research Center, Institute for the Study of Earth, Oceans and Space, University of New Hampshire, Durham, New Hampshire 03824, U.S.A.; cpw @ breeze.sr.unh.edu

(C) The Arctic Institute of North America
} 


\section{INTRODUCTION}

The environment of the Arctic has loomed large in the consciousness of archaeologists working in the region. Many studies of Thule and Historic Inuit archaeology of the last three decades, focusing on Baffin Island and Labrador, have used environmentally oriented explanations to frame culture histories and better understand adaptive change (e.g., McGhee, 1969/70; Fitzhugh, 1972, 1997; Schledermann, 1975, 1976; Jacobs, 1975, 1979; Dekin, 1978; Maxwell, 1979; Kaplan, 1983; Stenton, 1983, 1987; Savelle and McCartney, 1988; Sabo, 1991; Henshaw, 1995, 1999a, b; Woollett, 1999). These studies have also made extensive use of available palaeoenvironmental and zooarchaeological data to support arguments about the relationship of cultural changes to climatic changes and the accompanying shifts in the distribution of economically important prey species.

However, the task of establishing links between identified patterns in archaeological faunal assemblages, inferred changes in animal populations, and environmental change has proved difficult. Recurring problems often encountered in these studies include the difficulties involved in correlating time-averaged records with more precisely dated data; the problematic relation of large, regional-scale reconstructions to local studies; and the challenges posed by the frequently oblique relationship of measured environmental variables to adaptive cultural behaviour observed in terms of settlement patterns, technology, and subsistence economy. As noted by Jacobs (1985), the ambiguity associated with these chronological and ecological relationships impedes the correlation of cultural phenomena and palaeoenvironmental changes beyond the level of general culture and climate history.

Recent advances in palaeoenvironmental research offer solutions to some of these problems. Perhaps most notable is the development of diverse high-resolution environmental records based on ice core research. Nearly the whole perimeter of the northwest Atlantic and Eastern Arctic regions is now linked by glaciochemical studies based in Greenland, Ellesmere Island, Devon Island, Baffin Island, and Iceland (Koerner, 1977; Koerner and Fisher, 1990; Fisher and Koerner, 1994; Mayewski et al., 1994; Meese et al., 1994; Grumet, 1997; ICWG, 1998). These investigations provide well-dated regional climate reconstructions with high temporal resolutions, often at annual and seasonal scales. Perhaps more importantly, glaciochemical studies provide proxy indicators for a suite of environmental features, such as sea ice, that are critical for understanding palaeobiogeography and human adaptation in the North. Several historic sea ice studies reinforce the glaciochemical sea ice records (Newell, 1983, 1990; Teillet, 1988; Catchpole, 1992; Ogilvie, 1992). Thus we now have an opportunity to re-examine archaeological explanations in terms of these new high-resolution environmental data.

To explore some of the ways in which archaeological data may contribute to current reconstructions of arctic palaeoenvironments, we examined zooarchaeological data from Thule and historic Inuit settlements in Baffin Island and Labrador that were occupied during the Little Ice Age (see Fig. 1). Our goal is to investigate how archaeological data can aid in approaching questions about long-term relationships between subsistence economies, seal populations, and sea ice conditions in selected areas. Using biological, climatological, and archaeological data together provides a means to build histories of landscapes and seascapes, as well as a method to place current Arctic environmental change into broader temporal contexts.

\section{INDICATOR SPECIES AND ARCHAEOLOGICAL BIOGEOGRAPHY}

In recent years, the biological ramifications of climate change and the use of certain Arctic species as practical indicators of climate change-fundamental issues for global change research generally and for palaeoecological reconstructions in particular-have drawn increasing attention (see McCauley and Meier, 1991; Stirling and Derocher, 1993; Tynan and DeMaster, 1997; Stirling et al., 1999). These studies focus on the dynamic relationships between the seasonal range, demography, and life history of various species and the discrete environmental variables that define habitats and limit ecological niches. In the North Atlantic, sea ice is a key habitat-defining variable for all seal species, as their reproductive capacities, range, feeding, and migration behaviours are highly sensitive to changes in climate and sea ice cover (Smith, 1973, 1987; Smith et al., 1991). Populations of these species might therefore be considered indicators of the sea ice conditions that structure their habitats. Accordingly, observation of fluctuations in populations of these species offers an opportunity to examine the nature and pace of ecological change linked to dynamic climate in the Arctic today (Tynan and DeMaster, 1997; Stirling et al., 1999).

This study focuses on ringed seals, harbour seals, harp seals, bearded seals, and walrus as indicators of sea ice changes. These species are selected for their specific habitat requirements, characteristic relationships with sea ice, and importance in Inuit subsistence economies in Baffin Island and Labrador. The ringed seal, a cornerstone of Inuit winter subsistence, is the archetypal ice-adapted seal: much of its annual cycle revolves around ice. Fast ice is a primary winter habitat for ringed seals; they rely on the protection and the uncontested niche it provides. Ringed seals moult and bask on spring ice, and they exploit drift ice environments, as well as open water, in summer (McLaren, 1958; Mansfield, 1967; Smith, 1973; Boles et al., 1980). Ringed seals demonstrate a degree of agespecific territoriality in winter and spring, wherein lies much of their interest as an indicator species. Larger, mature, individuals (seven years old and older) tend to occupy fast ice areas (Smith, 1973; Ames, 1977; Boles et al., 1980). Infant pups usually linger around their birth 


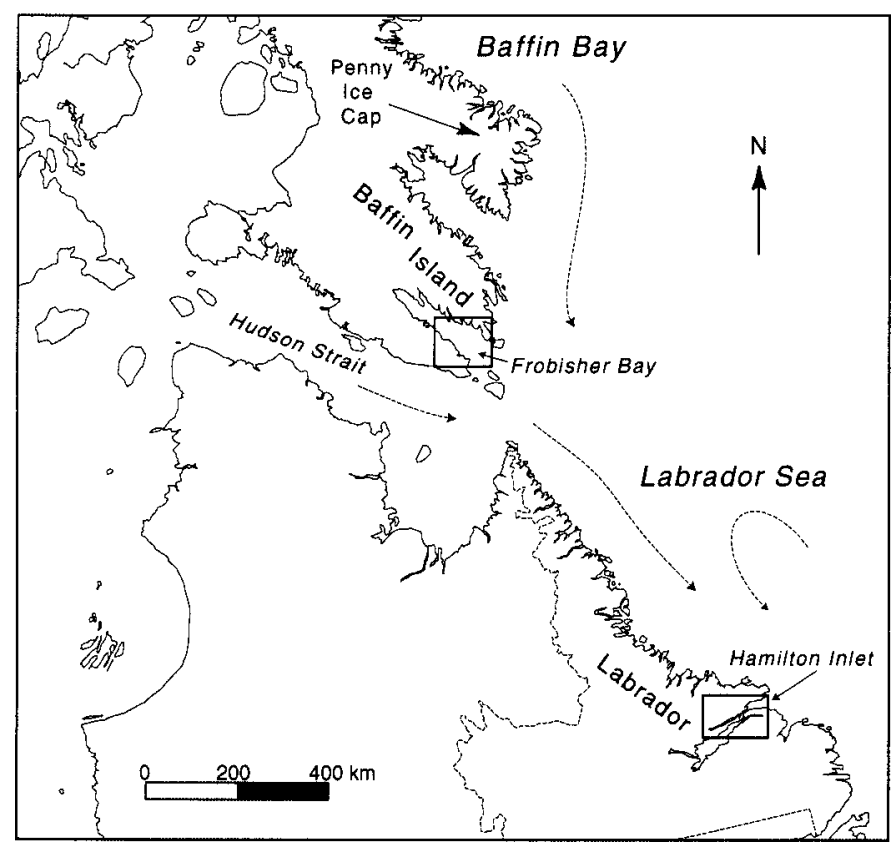

FIG. 1. The North Atlantic/Eastern Arctic region, showing study areas on Baffin Island and Labrador (boxes) and major ocean currents (arrows).

lairs after weaning, so they are also limited to fast ice areas until breakup (Smith, 1987). Open water areas in polynyas and at the ice edge are left primarily to juvenile individuals from one to seven years old (Smith, 1973, 1987).

In contrast to ringed seals, harbour seals generally avoid heavy winter ice environments, and they do not make or use breathing holes in fast ice (Bigg, 1981). In the Atlantic and Eastern Arctic, groups of harbour seals tend to haul out on shores and skerries, rather than ice floes, to pup and to bask (Bigg, 1981). They are not migratory, but they move seasonally from feeding and hauling-out places in bays, rivers, and along coasts during the ice-free months, to the ice edge and ice-free areas during the winter months (Ames, 1977; Boles et al., 1980).

Harp seals also avoid fast ice, seeking open water and loose, moving pack ice (Sergeant, 1991). Harp seals are migratory: they are present in the locations discussed in this paper during their northward (spring) and southward (fall) migrations. Their greatest potential as an indicator species in these regions may therefore lie in noting their availability during these periods and the timing of their migrations, rather than in providing detail about winter conditions.

Bearded seals are associated with the productive waters of the ice edge, with light drifting pack ice, and with polynyas. They can maintain breathing holes in new, thin ice, but they avoid thick fast ice and heavy drift ice (Burns, 1981). They feed on benthic organisms and so seek out places where the ice edge allows access to shallows. Walrus are associated with similar conditions, preferring shallows with thin ice, loose pack ice at the floe edge, leads, and polynyas (Stirling et al., 1981). Neither species migrates on a large regional scale.
The use of these species as indicators of environmental conditions is of specific value in resolving questions about long-term patterns of past, as well as contemporary, environmental change in the Arctic. Provided with suitable sources of biogeographic and life history data, long-term biological studies can broaden climate-centred models of environmental change. This kind of research is also pertinent to global change studies because it can examine aspects and scales of environmental change that are not easily documented in the comparatively narrow window provided by modern, short-term biological studies or instrumental records. Consequently, diachronic studies of fauna change in selected regions are of interest to biologists, ecologists, and climate change modelers, as well as to archaeologists.

However, there are few, if any, direct sources of information about sea mammal populations in the past. Two sources of alternative proxy data, both related to human interaction with these indicator species, are archived catch statistics and skeletal faunal remains recovered from archaeological sites. Catch statistics have been used effectively in several palaeoecological studies, but they apply only to recent time periods and to particular species and regions. Faunal remains constitute a unique and promising source of biological information because of the kinds of analyses they can support and because both archaeological sites and archaeological bone remains are common in comparison to relatively isolated palaeontological finds. Zooarchaeological analyses can address the relative frequencies of animals taken by hunters and provide the details of demography, health, and seasonality of hunted populations needed to define changes in range, life history, and migration.

Nevertheless, faunal remains are problematic sources of palaeobiogeographic data. Grayson (1981) correctly criticized the use of simple zooarchaeological taxonomic abundance data as a straightforward palaeoecological record, observing that the original populations represented by archaeological bone collections were hunted-and therefore humanly selected-populations, rather than whole, living communities. Variable preservation and the indirect relationship between numbers of hunted individuals and their preserved and quantified remains place additional burdens upon literal interpretations of species abundance data (Grayson, 1981). For these reasons, Grayson (1981) favoured the use of simple presence/absence attributes for palaeoecological studies involving whole archaeological assemblages. We argue that zooarchaeology can indeed provide useful palaeobiogeographic information when regional comparisons of abundance data for particular indicator species in sensitive environments are reinforced by several other kinds of data, including seasonality and life history data, well-established chronological and taphonomic controls, and independent palaeoenvironmental data. These regional comparisons can be used to indicate trends in hunted populations, rather than direct records of populations themselves. 
Within these limits, suitable zooarchaeological studies can provide useful proxy information about hunted populations and indirectly about past living communities. This perspective posits a strong, if partial, relationship between the structure of hunting and gathering peoples' subsistence economies (the kinds of resources they procure, how they procure them, and how they are used) and those resources that ecological circumstances make plentiful, accessible, and practical (see Lyman, 1988). Economic decisions are very much influenced by cultural priorities, and the Inuit have long had the skills and technological capacity to use most, if not all, food resources in their environments. However, access to preferred prey resources when they are predictable and plentiful is a key factor shaping people's decisions regarding species choice, seasonal rounds, and settlement location. Accordingly, we concentrate on species that have important roles in subsistence as well as specific habitat requirements, with the objective of defining biogeographical trends in these indicator species rather than precisely defining whole living communities in the past.

Zooarchaeology contributes to palaeobiogeography by applying a regionally comparative approach and using the areal coverage and time depth provided by multiple archaeological sites to define spatial and temporal patterns of species use (Amorosi et al., 1996). A number of conditions must be met for reliable interassemblage comparisons. The date and provenience of samples must be well established and comparable to sources of independent, high-resolution palaeoenvironmental records. Furthermore, the sizes of faunal collections must be sufficient to support the questions asked of them and to ensure comparability of quantitative measures. Frequently, samples of about one thousand to several thousand bone fragments per assemblage are considered optimal, if not necessary (Amorosi et al., 1996). Attrition of archaeological bone remains through chemical weathering processes is often less of a problem in the Arctic than in more temperate regions: permafrost or frozen ground produces excellent bone preservation conditions in some localities. Nevertheless, taphonomic studies should be used to examine the extent to which bone assemblages may have been differentially biased by accumulation and attrition processes. Similar identification and quantification methods must also be used to ensure that data sets are comparable.

Even when all of these factors are understood, faunal assemblages from most archaeological sites provide proxies for hunted populations rather than direct, one-to-one representations of living communities (Amorosi et al., 1996). Therefore, measures of species abundance represent the first step in regional comparisons and are most useful as ordinal measures of temporal or spatial trends in groups of assemblages. In addition, it is possible to attribute ages of death for the archaeological population and to characterize elements of their life history through seasonality and growth studies (Klevezal, 1996). Together, these variables provide the analytical means of recon- structing subsistence by defining the character of the hunted population and the seasonal schedule of hunting activities. More complex zooarchaeological analyses therefore contribute data on both abundance and attributes, as Grayson's critique of zooarchaeological palaeoenvironmental studies requires, although these attributes are considerably more detailed than the presence/absence list he advocated. When trends in these subsistence variables coincide with pertinent palaeoclimate records, ecological changes may be indicated. This inference is strengthened when we compare sites in similar, environmentally sensitive contexts, such as ones located near the edge of landfast ice, pupping areas, or polynyas.

\section{SEA ICE, SEALS AND ZOOARCHAEOLOGY}

Arctic sea ice has been described as a bellwether of global climate change (McCauley and Meier, 1991). Sea ice directly shapes Arctic marine ecosystems, and its extent varies in relation to a range of environmental variables, including marine and atmospheric circulation, salinity, and climate (Crane, 1978; Barry et al., 1993). The historical relationships of climate, sea ice, and biology are also of specific importance to global change studies because they provide baseline data for interpreting the significance of environmental changes observed in the present world. Several recent studies have specifically reviewed the use of ice-related seals, bowhead whales, beluga whales, and polar bears as indicator species to examine modern ice conditions and modern global change processes (Stirling and Derocher, 1993; Tynan and DeMaster, 1997).

Recent glaciochemical, palaeontological, and archival research has done much to resolve questions about past sea ice conditions in the North Atlantic and Eastern Arctic regions (see Newell, 1983; Teillet, 1988; Catchpole, 1992; Ogilvie, 1992; Mayewski et al., 1994; O’Brien et al., 1995; Jennings and Weiner, 1996; Grumet, 1997; Grumet et al., in press). However, the nature of biological responses to these changes remains a problematic question because of the difficulty of sampling animal populations of the past. Vibe (1967) addressed this problem in his pioneering historical ecology study of West Greenland by comparing catch statistics of particular indicator species, reported by local hunters and fishermen, to climate records from the same period. In another set of recent studies, Meldgaard (1986, 1995) also concentrated on catch records of ecologically sensitive species. In these studies, fluctuations in the composition of contemporary Greenlanders' catches of whales, seals, and fish were correlated with the northsouth displacement of boreal and Arctic-adapted species, which was related, in turn, to changing climate and oceanic circulation. The indicator species approach has also been productively applied in several other ecological and archaeological studies (e.g., Dunbar and Thomson, 1979; Dyke et al., 1996; Sergeant, 1991; McGovern et al., 1993). While hunting statistics studies are very illuminating, they 
are obviously limited to the historic period and to cases when suitably assiduous and complete records were kept.

Skeletal seal remains preserved in the archaeological record offer an alternative source of past wildlife data that can be applied generally to a range of species, to whole regions, and over much longer time periods (Lyman, 1988, 1996; Amorosi et al., 1996). Some recent archaeological analyses have used subfossil bowhead whales and walrus as indicators of past ice conditions in the Canadian Arctic Archipelago (Dyke, et al., 1996, 1999; Savelle et al., 1998). Other species associated with well-defined ecological niches, such as seals, might also be useful as indicator species.

Polynyas, defined in a general sense as areas of open water surrounded in winter by ice or coastlines, might also be considered indicators of environmental change, as their fluctuating occurrence and configurations are symptomatic of regional fast ice formation, pack ice, tides, currents, and atmospheric conditions (Stirling, 1980, 1997; Stirling et al., 1981; Stirling and Cleator, 1981). While some large polynyas are relatively predictable from year to year (recurring polynyas), other, smaller ones may be more variable in occurrence and area and more responsive to regional climate change processes. The composition of species found within such polynyas may offer clues to their fluid characteristics or their size and frequency of occurrence over time (Schledermann, 1980; Stirling, 1980, 1997; Stirling et al., 1981; Gilchrist and Robertson, 2000). In general, faunas associated with larger polynyas may resemble those found at the floe edge or in open water, including bearded seals, walrus, harbour seals, and immature ringed seals. Smaller polynyas may display less species diversity but should still reflect age-specific ringed seal territoriality. Areas with irregularly occurring open water features should fluctuate between less diverse, fast ice faunas and faunas associated with open water. Accordingly, we focus on archaeological assemblages from localities with open water in winter or spring (or both) to examine the relationships between sea ice variability, polynya formation, and seal biogegraphic change in these regions over hundreds of years.

\section{ZOOARCHAEOLOGICAL MEASURES OF SPECIES ABUNDANCE}

Conventional taxonomic quantification methods include estimates of minimum numbers of individuals (MNI) and absolute counts of numbers of specimens identified to species (NISP). A large literature revolves around the application of these two techniques (e.g., Grayson, 1984; Lyman, 1994), and both have strengths and weaknesses that render them more or less appropriate for certain research questions and kinds of assemblages. Since MNI counting methods reduce sample size and have been derived by a variety of means, comparison of published data is often difficult. Generally, MNI counts are considered most usefully applied to contexts where carcasses enter the archaeological record as relatively whole units. NISP counts are generally more easily applied to small collections, so they represent a useful minimum level of quantification for interassemblage comparisons (Gilbert and Singer, 1982; Grayson, 1984; Amorosi et al., 1996). NISP counts are also considered more applicable to accretional deposits, such as middens, where portions of carcasses enter the archaeological record over extended periods as extensively subdivided or transported butchery units and reworked refuse deposits. To make the greatest use of the samples available, and because the collections used in this study are from such secondary or tertiary contexts, we used NISP counts as the standard source of general taxonomic data. While quantifications of taxa and interassemblage comparisons represent significant methodological challenges for zooarchaeology, a growing body of recent zooarchaeological research in the North Atlantic suggests that these are attainable goals and that NISP-based taxonomic counts can be usefully applied to specific research questions (Amorosi et al., 1996).

The means of deriving NISP counts for seal species in this study requires additional explanation. The postcranial skeletons of North Atlantic seals, especially the smaller species, are notoriously difficult to differentiate because of a remarkable degree of intraspecies variability. The conventional practice when multiple species of small seals are present has been to apply general taxonomic categories to most elements. Species-level identifications are then made only on selected elements (auditory bullae, bony palate, maxillae, mandibles, humeri) with more readily identified landmarks that distinguish all the small seal species of the North Atlantic (Spiess and Hedden, 1983; Møhl, 1986). This narrow range of elements typically produces a more restricted sample than would result if these species were quantified on the basis of a piecemeal range of post-cranial elements, but it is a conservative and standardized basis for identification. Fortunately, the auditory bullae, palate, mandibles, and distal humeri are some of the most dense and easily preserved elements of the seal skeleton (Lyman, 1994) and frequently end up being the elements used to make MNI counts for seals.

Taphonomic bone density and completeness indices (Marean, 1991) suggest that the assemblages considered here have indeed been biased by attritional processes (Henshaw, 1995; Woollett, 1996), with roughly comparable patterns of attrition within each group of sites. By employing uniform modes of quantification using durable and consistently identifiable elements, we obtained a measure of control over biases of attrition and quantification. Arguably, the seal NISP counts are adequate for regional comparisons at the level of ordinal trends. Furthermore, this study employs intraregional rather than interregional comparisons of assemblages, minimizing the scope of bias introduced by regional preservation differences. 


\section{LIFE HISTORY: AGE AND SEASONALITY STUDIES}

Zooarchaeologists often reconstruct human hunting practices by analyzing incremental structures in bones and teeth to determine the age and season of death of prey animals. For species that exhibit age-set specific range and migratory behaviours, such as ringed seals and harp seals, age and season of death data provide information on the availability of different species and age groups in different environments and times of year. The frequency of these species and age groups in specific localities depends to a large degree on habitat structured by ice conditions. Similarly, hunters' ease of access to these animals depends on the hunting platform, be it fast ice or open water. Therefore, age and season of death studies provide critical information to tie zooarchaeological species counts to particular hunting activities in specific kinds of environments. Because archaeological data combine time depth and geographical representation with population, distribution, and life history information, they are potentially very informative, especially when linked with indicator species and high-resolution, long-term proxy climate and environment records.

Both age and season of death data for this study were derived from microscope examination of incremental structures in seal teeth, following formats outlined by Mansfield and Fisher (1960), Smith (1973), Bowen et al. (1983), Dietz et al. (1991) and Klevezal (1996). These methods have long been used in biological studies and have proved practical in well-preserved archaeological materials.

\section{LIFE HISTORY AND GROWTH}

The possibility of using osteometric observations to document growth patterns of archaeological seal populations has been considered in archaeological studies, though not stringently. Stanford (1976) measured a variety of adult seal skeletal elements from the Walakpa site in Alaska to determine whether postulated climate changes had correlated effects on animal populations. Stanford's study was hampered by limited sample size and therefore has uncertain significance, but he was able to show that recovered ringed seal bones (and presumably live seals as well) were larger in periods of inferred climate cooling (Stanford, 1976).

There is some zoological debate about the precise causes of stunting in adult seals. However, the nutritional status of pups is considered to be of central importance to growth because a substantial proportion of growth occurs by the time of weaning (see Smith, 1987; Smith et al., 1991). Smith (1987) suggested that the timing of birth was a very important variable influencing growth of young ringed seals: in his Western Arctic samples, many of the pups born later in the year were in poor condition and had stunted growth. The suckling periods of late-born pups may be shortened by the onset of ice breakup, forcing pups to compete with adult seals for food. A certain proportion of every year's cohort might therefore be stunted. In years of exceptionally poor food availability, whole cohorts might exhibit high incidences of stunting and poor condition.

Several researchers have suggested that ice conditions may directly influence the time of weaning, with more stable ice promoting longer suckling periods and greater infant growth among ringed seals (McLaren, 1958; Mansfield, 1967). McLaren (1958) and Finley et al. (1983) reported that ringed seals born in unstable ice conditions or along simple, exposed shorelines tend to be smaller and less robust than those born in the anchored ice of complex coastlines. It seems likely that the pup growth rates and adult absolute body length are related to the character of the ice environment, whether sea ice instability is the driving force or merely accentuates a tendency. Osteometric analyses therefore present one additional means by which biological responses to changing ice conditions might be observed through archaeological data.

\section{ENVIRONMENTAL CHANGE DURING THE LITTLE ICE AGE}

The Little Ice Age (LIA), conventionally dated from the 13 th to the 19th century (Grove, 1988), has been considered as an extended period of both glacial advance and general climatic cooling in the North Atlantic. New palaeoenvironmental and palaeoclimate research has shown that it was one of the periods of most rapid and drastic climate change during the Holocene (Mayewski et al., 1994; Meese et al., 1994; O’Brien et al., 1995). The glacioclimatological studies of the Greenland Ice Sheet Project 2 (GISP2) and other research have also shown that, while the LIA was generally characterized by periods of increased cold and glacial advance, it was not a period of spatially or temporally uniform cold (Bradley and Jones, 1993; Meese et al., 1994).

Figure 2 presents a 600 -year proxy sea ice record for Baffin Bay, based on glaciochemical analysis of an ice core from the Penny Ice Cap (PIC), located on the Cumberland Peninsula, Baffin Island (Grumet, 1997; Grumet et al., in press). This record parallels the general climate trends established by analyses of the GISP 2 cores from the Greenland ice sheet (Mayewski et al., 1994), the percent ice melt record of the Devon Ice Cap (Fisher and Koerner, 1994; Grumet, 1997; Koerner, 1997), and average annual temperature trends derived from Northern Hemisphere dendroclimatological studies (D'Arrigo and Jacoby, 1992). In the PIC record, sodium (derived from airborne sea salt) is considered to be a negative proxy indicator of regional sea ice extent and is most strongly related to spring ice conditions (Grumet, 1997; Grumet et al., in press). Reduction of sea ice in Baffin Bay increases the source region for windborne transport of sea salt onto the ice cap, while more severe ice conditions diminish the 
A

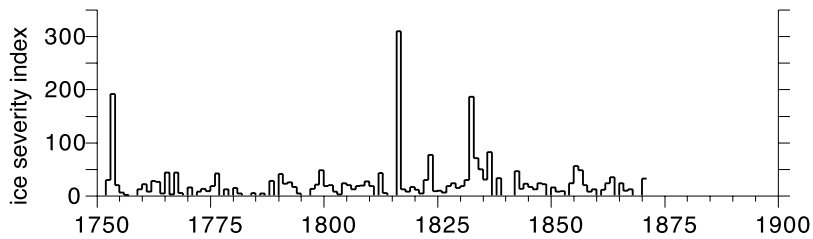

B

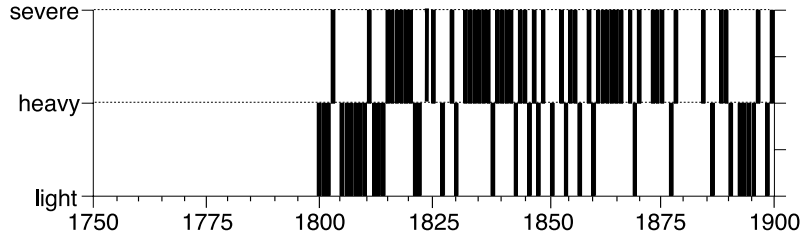

C
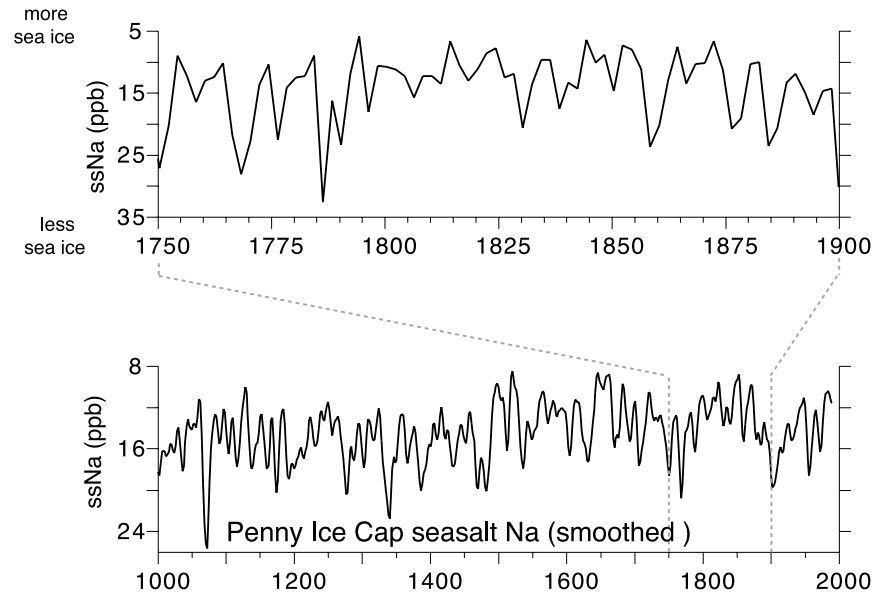

FIG. 2. Proxy records of historical sea ice conditions in Baffin Bay and the Labrador Sea. A) Teillet's ordinal Labrador Sea Ice Severity Index (Teillet, 1988) based on the logs of Hudson's Bay Company ships passing through the Labrador Sea. B) Newell's Most Severe Ice Code record for the Labrador Sea, based on ships' logs and shore-based observations (Newell, 1983). C) The Penny Ice Cap proxy ice record, based on concentrations of aerosol seasalt sodium in glacial ice layers (data from Grumet, 1997; in press).

source region. In contrast to the Penny Ice Cap record, the GISP2 sodium record provides a proxy for regional atmospheric circulation above the North Atlantic. It indicates strengthened polar circulation during a period of intensified sea ice in Baffin Bay, conditions that dominated much of the Little Ice Age (Mayewski et al., 1994).

Both sea ice concentrations and transport of sea salt aerosols are linked to regional atmospheric pressure (Crane, 1978; Grumet, 1997). Dates of spring ice clearance in Baffin Bay during the 20th century are correlated to the strength of spring southerly winds, which are, in turn, related to North Atlantic Oscillation atmospheric pressure variability. Years with late ice removal have the stronger westerly circulation and generally colder conditions associated with a deep Icelandic Low, while strengthened southerly winds brought by a high Icelandic Low create generally warmer temperatures and more rapid ice removal (Crane, 1978; van Loon and Rogers, 1978; Rogers and van Loon, 1979).
Ocean currents bring cold, low-salinity seawater, along with pack ice, from Baffin Bay into Davis Strait and Hudson Bay, influencing both climate and ice conditions in southern Baffin Island. The Labrador Current brings this water and its ice load farther south, along the Labrador coast toward Newfoundland. The PIC record is therefore an important indicator for reconstructing spring ice conditions in southern Baffin Island and Labrador.

The PIC sodium record shows a high degree of decadal to centennial variability in sea ice extent since ca. A.D. 1500 , reinforcing the characterization of the LIA as a period of considerable variability, rather than one of uniformly cold conditions and severe sea ice. Extended periods of generally light ice conditions are indicated for the early 14 th, the late 14 th to mid 15 th, and the early 16 th centuries. The mid 16 th to mid 17 th century is shown to have been a period of generally more severe ice conditions, after which cycles of moderating ice conditions persisted until the late 18 th century. A rapid change to severe ice conditions in the mid 19th century was followed by subsequent moderation in the late 19th century. Ice conditions in the opening decades of the 20th century steadily grew more severe until about 1916, after which they underwent rapid, short-term fluctuations between relatively moderate and heavy states until about 1940 (Grumet, 1997). Archival studies of ice conditions in the Labrador Sea further bolster the picture of regional patterning of ice conditions since the mid 18th century. An ordinal ice severity index for the Labrador Sea that spans the years from A.D. 1751 to 1870 , developed by Teillet (1988), demonstrates considerable annual variability in ice conditions (see Fig. 2). Teillet's index is based on observations of ice conditions in the northern Labrador Sea that were recorded in the logbooks of ships traveling to and from Hudson Strait. While mild and severe years were indicated throughout the record, the years from A.D. 1751 to about 1815 generally produced low ice severity rankings. The clear majority of years with high ice severity rankings came after A.D. 1815, and the decade 1830-40 was particularly severe.

Newell's (1983) historical sea ice record for the 19thcentury Labrador Sea, derived mostly from spring and summer observations of ice conditions by ship and shorebased observers, shows a trend roughly similar to that illustrated in Teillet's index (see Fig. 2). The years before A.D. 1815 were marked primarily by light ice conditions, punctuated by brief periods of ice that was heavy to severe relative to modern conditions. Periods of heavy ice are indicated for 1815-20, 1833-43 and 1860-68.

A summer ice severity index has also been compiled for the Hudson Strait and Hudson Bay (Catchpole and Faurer, 1983; Catchpole, 1992). These indices approximate pack ice severity and ice clearance dates through the dates and duration of the westward passage of ships through Hudson Strait and through direct observation of ice conditions recorded in logbooks. While there is some degree of divergence between the Hudson Strait and Labrador Sea 
ice indices, which is probably due to the former region's distinct circulation patterns, the sea ice analyses of both regions indicate that especially heavy summer ice conditions existed in the years around A.D. 1816, in the later 1830 s, and in the mid to late 1860 s. The general consistency with which the various ice severity records and the Penny Ice Cap proxy sea ice record identify periods of exceptionally heavy ice suggests that regional sea ice trends can be measured as well as local variation.

\section{THE NARROWS: A CASE STUDY OF SEA ICE AND SEAL HUNTING IN LABRADOR}

Because of its geography and hydrography, the Narrows region of Hamilton Inlet in central Labrador presents an excellent opportunity to demonstrate the archaeological visibility of biological changes linked to sea ice changes. The Narrows Strait links Groswater Bay with Lake Melville, a deep fjord that stretches over $100 \mathrm{~km}$ into Labrador's interior (Fig. 3). Fast ice forms in Groswater Bay and Lake Melville in late December, but strong tides in the Narrows sweep this strait free of ice, often forming a large area of open water extending from the Narrows into southern Groswater Bay (Ames, 1977). In years of heavy ice or severe cold, fast ice or wind-driven pack ice may clog Groswater Bay and the entrance to the Narrows, separating these open water areas from each other and from the ice edge in northern Groswater Bay (USNHO, 1941; Fitzhugh, 1972; Ames, 1977). In rare circumstances, the Narrows itself sometimes freezes over for a limited time (USNHO, 1941).

In summer, harbour seals frequent the heads of sheltered bays (such as Double Mer and the Back Bay) and river and stream mouths around Groswater Bay, where they find rich feeding grounds and breeding areas (Ames, 1977). In winter, harbour seals live at the ice edge in northern Groswater Bay and may range farther inland when the entrance to the Narrows is ice-free (Ames, 1977).

Ringed seals are found throughout the area in summer; but in winter, the majority of mature ringed seals seek out breathing-hole habitat in Lake Melville and adjacent sheltered fjords, while immature ringed seals may remain in the Narrows as well as at the ice edge in Groswater Bay (Ames, 1977). Harp seals are very common in the area during their spring and fall migrations. In the 20th century, the major harp seal hunt has been during the fall, lasting until the winter freeze-up (Ames, 1977).

Several archaeological sites dot the Narrows area, dating from the earliest known Inuit settlement of the region in the 17th century to the present day. Excavations at three settlements located on Eskimo Island (GaBp-1, 2 and 3), in the midst of the Narrows Strait, contributed faunal collections to this study (Jordan, 1977). These sites were occupied successively in the 17th, 18th, and 19th centuries (Fitzhugh, 1972; Jordan, 1974, 1977; Kaplan, 1983). Dates for these assemblages were attributed on the basis of recovered artifacts, particularly time-specific European

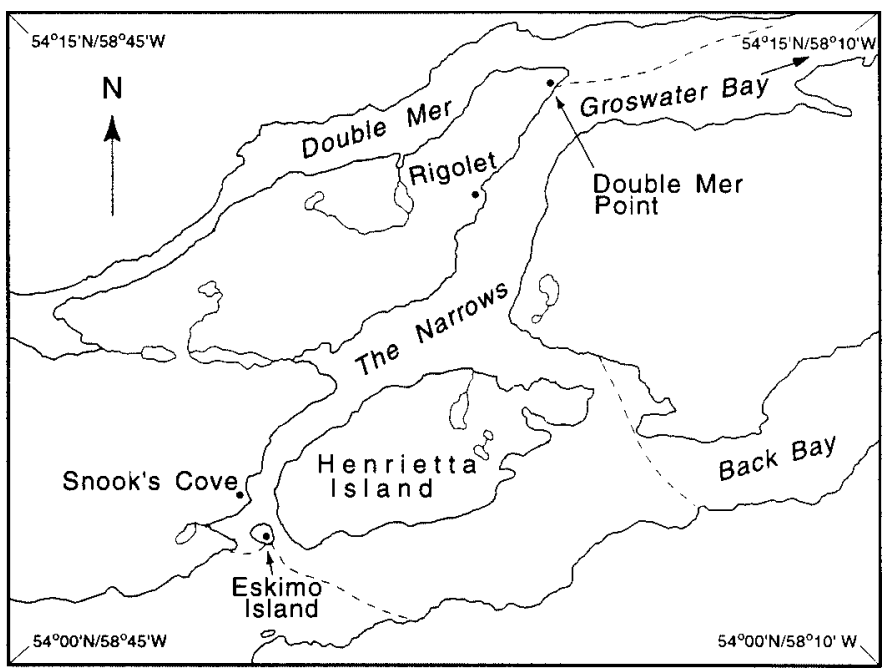

FIG. 3. Map of the Narrows region, Hamilton Inlet, coastal central Labrador. The dashed line indicates the approximate limit of the ice edge in the Narrows. The western perimeter of the Narrows is bounded by fast ice covering Lake Melville, extending to the western shore of Eskimo Island. Fast ice covers the entrances of the Back Bay to the east, and Double Mer to the north, as well as the northern shore of Groswater Bay.

trade goods, and hence are difficult to resolve at decadal scales (see Kaplan, 1983). Small faunal collections were also obtained from two more settlements lying on the northern shore of the strait, at Snook's Cove (GaBp-7) and Double Mer Point (GbBo-2). Woollett (1999) published initial zooarchaeological analyses of faunal assemblages from these sites; here we present final species identifications for seal specimens (see Fig. 3 for location of sites).

The faunal remains used in this study came primarily from excavations in sod house contexts, though limited excavations in middens were also undertaken (Jordan, 1974). Excavations of varying scales were made in four 17 th-century houses, three 18th-century houses, and three 19th-century houses (Jordan, 1974, 1977). The sites' faunal assemblages are similar in size, with approximately 3000 specimens identified to species in each chronological category (Woollett, 1999).

Artifact collections from these sites included large numbers of trade goods, indicating extensive trade with Europeans. The opportunity to trade may have been a major stimulus for Inuit settlement in the region. Seal skins were part of this trade, though much more European commercial demand existed for whale baleen and rendered blubber before the 19th century and for fish and furs afterwards (Ames, 1977; Kaplan, 1983, 1985).

Eskimo Island, in particular, is an excellent location for winter and spring seal hunting: it lies at the juncture of open water and fast ice, with the open water of the Narrows on its eastern shore and a spit of the Lake Melville fast ice anchored to its western shore. From this location, Inuit hunters would have had ready access, traveling on foot, with boats, and with dog sleds, to a range of seal habitats. The site of Double Mer Point is also favoured by immediate proximity to extensive fast ice and open water areas. 
Frequency distributions of specimens identified to species are presented in Table 1, with percentages of the seal assemblage shown in parentheses. Harp seals are the dominant taxon in most of the assemblages from these sites. They are most common in the 17th-century assemblage of Eskimo Island 3, where they comprise about $59 \%$ of the identified seal assemblage. Harp seal remains are less common in the 18th-century assemblages of Eskimo Island 1 and Double Mer Point (45\%) and especially in the early to mid 19th-century assemblages of Eskimo Island 2 (36\%). Ongoing analyses of dental annuli in a small sample of well-preserved harp seal teeth suggest that these seals were taken primarily during their southward fall migration (see Table 2). The fall migration would likely have been of critical economic importance: during this season, harp seals are in prime condition, more readily accessible, and more easily recovered when killed, and they would have provided a storable surplus of meat for use in the winter. In contrast, harp seals taken during their northward spring migration tend to be lean and less useful for food, and harder to recover because they sink when killed (Ames, 1977). They may be inaccessible, as well, if rotten ice or pack ice keep them away from the shore. No grey seal specimens and only a handful of bearded seal specimens were identified in the Eskimo Island collec- tions, nor were there many conspicuously large pinniped bones that might have belonged to one of these species.

Ringed seal specimens comprise $23 \%$ to $46 \%$ of the seals represented in these assemblages, and are most frequent in the 17th and 19th-century assemblages. Preliminary season-of-death estimations for a small sample of available teeth (Table 2) indicate that ringed seals were taken in winter and spring in all periods represented. Also, the sample is almost entirely composed of mature individuals. While the sample is small, this pattern suggests that ringed seal hunting was concentrated on adults found on and around landfast ice, rather than on subadults found in open water.

Harbour seal specimens range from $10 \%$ of speciesidentified seal bones in the 17th-century contexts to $32 \%$ of those in the 18th-century sites and $42 \%$ of those in the mid to late 19th-century site of Snook's Cove. Analyses of dental annuli indicate winter and spring deaths for harbour seals in the 18th-century assemblages. The sample is very small but does demonstrate the presence of harbour seals in the Narrows in winter during this period.

The relationships between frequency distributions of the three major seal species are further examined in Table 3. They are expressed as ratios, for example, ringed seal NISP by harp seal NISP. Equivalent proportions of

TABLE 1. Frequencies of seal bones (NISP) in archaeological assemblages from the Narrows region, Hamilton Inlet, Labrador. \%NISP is given in parentheses.

\begin{tabular}{|c|c|c|c|c|c|c|c|c|}
\hline \multirow[b]{2}{*}{ Ringed Seal } & \multicolumn{2}{|c|}{$\begin{array}{l}\text { Eskimo Island } 3 \\
\text { (17th century) }\end{array}$} & \multicolumn{2}{|c|}{$\begin{array}{l}\text { Eskimo Island 1/Double Mer Point } \\
\text { (18th century) }\end{array}$} & \multicolumn{2}{|c|}{$\begin{array}{l}\text { Eskimo Island } 2 \\
\text { (early 19th century) }\end{array}$} & \multicolumn{2}{|c|}{$\begin{array}{l}\text { Snook's Cove } \\
\text { (mid-late 19th century) }\end{array}$} \\
\hline & 112 & $(30.1)$ & 43 & $(22.5)$ & 84 & (45.9) & 10 & (27.8) \\
\hline Harbour Seal & 39 & $(10.5)$ & 61 & (31.9) & 31 & (16.9) & 15 & 41.7) \\
\hline Harp Seal & 221 & $(59.4)$ & 86 & $(45.0)$ & 66 & (36.1) & 11 & $30.6)$ \\
\hline Bearded Seal & & & 1 & $(0.5)$ & 2 & (1.1) & & \\
\hline Total NISP & 372 & & 191 & & 183 & & 36 & \\
\hline
\end{tabular}

TABLE 2. Summary of season and age of death estimations of seals based on incremental structures in canines, in archaeological assemblages from the Narrows region, Hamilton Inlet, Labrador.

\begin{tabular}{|c|c|c|c|}
\hline Age of Death & $0-1$ Years & 1-6 Years & $7+$ Years \\
\hline \multicolumn{4}{|l|}{ Ringed Seal } \\
\hline Eskimo Island 1/Double Mer Pt., 18th century & & 1 & 3 \\
\hline Eskimo Island 2, early to mid 19 th century & & 2 & 3 \\
\hline \multicolumn{4}{|l|}{ Season of Death } \\
\hline \multicolumn{4}{|l|}{ Harbour Seal } \\
\hline Eskimo Island 1/Double Mer Pt., 18th century & 1 & 1 & 1 \\
\hline \multicolumn{4}{|l|}{ Ringed Seal } \\
\hline Eskimo Island 3,17 th century & & & 1 \\
\hline Eskimo Island 1/Double Mer Pt.,18th century & & 3 & 1 \\
\hline Eskimo Island 2, early to mid 19th century & & 1 & 2 \\
\hline
\end{tabular}


numerator and denominator result in a ratio of 1.00 , while larger numbers indicate relatively greater scales of the numerator. The proportion of ringed seals to harp seals is quite similar in the 17th and 18th-century assemblages, with harp seals being about twice as common. Ringed seals were much more common in the 19th-century assemblages. The ringed seal/harbour seal ratios show a different chronological trend. Very similar high ratios of ringed seal remains to those of harbour seals are noted for the 17th- and 19th-century assemblages. Hunting in heavy winter and spring ice conditions would likely produce high proportions of ringed seals. However, a very different pattern is shown for the 18th-century collections and the middle to late 19th-century collection, with greater proportions of harbour seal remains represented.

Because harp seals were taken primarily in the fall and the ringed seals represent predominately winter and spring kills, the ringed seal/harp seal ratio represents a measure of the scale of hunting on and around sea ice versus open water hunting in fall. These ringed seal/harp seal ratios suggest that fall open water hunting was consistently of major importance in the 17th and 18th centuries, and that relatively more effort was invested in winter hunting on and around sea ice in the early to mid 19th century. This pattern may suggest that the harp seal hunting season was shorter during the early to mid 19th century or that fewer harp seals were available to coastal hunters, conditions which would agree with the heavy sea ice conditions indicated for this period. However, because the ringed seal and harp seal hunts were not synchronous, this ratio is likely of limited value as an indicator of environmental conditions during the winter and early spring.

Both harp and harbour seals are typically associated with open water and mixed, loose ice. If harbour seals were hunted primarily in the fall, along with harp seals, it would be reasonable to expect that archaeological harp and harbour assemblages would co-vary in terms of NISP frequency and seasonality. However, the ringed seal/harbour seal NISP ratio trend is quite different from the ringed seal/ harp seal NISP ratio. It increases dramatically in the 18thcentury assemblages, while the ringed seal/harp seal NISP ratio remains static at levels similar to those of the 17 th century. Although it is likely that harbour seals were indeed hunted in the fall along with harp seals, harbour seals were also taken in the Narrows during the winter and spring in the 18th century. Therefore, the increased fraction of harbour seals in the 18th-century assemblages is likely due in part to this extended hunting season, which was encouraged by the presence of harbour seals in the Narrows well after migrating harp seals would have left the region. As discussed earlier, the modern extent of fast ice in the Narrows favours ringed seals during winter and spring (Ames, 1977). The presence of harbour seals in the locale is therefore suggestive of moderated ice conditions.

If the archaeological ringed seal/harbour seal ratio reflects past sea ice conditions, relatively moderate ice conditions with open water in the Narrows and Groswater
Bay may be indicated for the 18th and later 19th centuries. This pattern agrees with that demonstrated in Teillet's Labrador Sea ice severity index. In recent years, open water has at times stretched from the Narrows to the ice edge in Groswater Bay, opening the Narrows to species overwintering at the ice-edge, including local harbour seal populations (Ames, 1977).

Similarly, the high proportions of ringed seals at the 17 th- and early 19 th-century sites are consistent with the relatively heavy ice conditions indicated by the historic ice indices and the Penny Ice Cap proxy ice record. Heavy ice in the Narrows would have been manifest in more fast ice around Eskimo Island and pack ice enclosing or completely in-filling the Narrows. These conditions would have sealed off the Narrows from Groswater Bay and excluded harbour seals living at the ice edge. As well, the presence of dense pack ice in the Narrows likely would have hindered the efforts of Inuit to hunt within the strait itself and encouraged the hunting of mature ringed seals and pups on the fast ice of Lake Melville.

Alternatively, the increased proportion of ringed seals in the 19th-century assemblages could reflect market demand for seal products and intensified hunting effort using new technologies, such as firearms and seal nets. Both of these factors likely had significant roles in the economy of the 19th-century Labrador Inuit, but still presume the presence of appropriate seal populations and the fast-ice hunting platform. Nets, in themselves, are an especially nonselective hunting technology. The greatly reduced take of harbour seals in the early to mid 19th century makes a strong argument that harbour seals were found comparatively less often in the Narrows in winter during this time. Because no harpoons were recovered, it is as yet impossible to infer the relative importance of open water or fastice hunting techniques on the basis of specialized seal hunting technology. Hunting technology analyses represent one possible future means of reinforcing environmental indications based on zooarchaeological seal life history studies.

\section{SEA ICE AND SEAL HUNTING IN OUTER FROBISHER BAY}

A recent archaeological study in the Frobisher Bay region provides another opportunity to explore the historical relationships between seal populations and sea ice conditions associated with a polynya. Three archaeological sites located on the eastern coast of outer Frobisher Bay-Kuyait (KfDf-2), Kamaiyuk (KfDe-5), and Kussejeerarkjuan (KeDe-7) — were excavated by the Meta Incognita Project in 1991 and 1992 (Henshaw, 1995; Gullason, 1999; Fig. 4). These sites are situated in Countess of Warwick Sound, adjacent to a large polynya in outer Frobisher Bay (see Smith and Rigby, 1981: Fig. 1; Stirling, 1997: Fig. 1; Stirling and Cleator, 1981). The inhabitants of these sites relied heavily on the procurement of 
TABLE 3. Ratios of seal NISP counts for archaeological assemblages from the Narrows region, Hamilton Inlet, Labrador.

\begin{tabular}{lcccc}
\hline \hline & $\begin{array}{c}\text { Eskimo Island 3 } \\
\text { (17th century) }\end{array}$ & $\begin{array}{c}\text { Eskimo Island 1/ Double Mer Pt. } \\
\text { (18th century) }\end{array}$ & $\begin{array}{c}\text { Eskimo Island 2 } \\
\text { (early 19th century) }\end{array}$ & $\begin{array}{c}\text { Snook's Cove } \\
\text { (mid-late 19th century) }\end{array}$ \\
\hline Ringed Seal/Harp Seal Ratio & 0.51 & 0.5 & 1.27 & 0.91 \\
Ringed Seal/Harbour Seal Ratio & 2.87 & 0.7 & 2.71 & 0.67 \\
\hline \hline
\end{tabular}

marine mammals in this relatively rich and predictable environment (Gullason et al., 1993; Henshaw, 1995, 1999a, b).

Archaeological excavations at these sites were conducted in both qarmat (winterized tent structures) and large, bilobate semisubterranean sod house structures. On the basis of radiocarbon dating and artifact analyses, the assemblages from Kamaiyuk used in this study have been dated to the 16th to 19th century A.D., those from Kuyait to A.D. 1920-30 and those from Kussejeerarkjuan to A.D. 1910-30 (Gullason, 1999). Artifact assemblages consist of both European trade goods and traditional Inuit hunting and food processing technology (Gullason, 1999).

The outer Frobisher Bay region includes a recurring polynya bounded to the north, south, and west by fast ice forming in the bay and along the shores of the Meta Incognita and Hall Peninsulas, and to the east by pack ice lying off Frobisher Bay (see Henshaw, 1999: Fig. 1). Environmental variables may influence the extent and periodicity of polynyas in general by modifying the location and stability of fast ice and pack ice boundaries. The extent and thickness of winter fast ice within Frobisher Bay has been positively linked to winter temperature in particular (Crane, 1978; Henshaw, 1995, 1999b). In recent years, the general location of the floe edge in outer Frobisher Bay, near Countess of Warwick Sound, has been constant despite fluctuations in regional ice severity, making the area attractive to open-water species as well as to those associated with fast ice (Henshaw, 1999b). Other factors, such as tidal fluctuations, currents and upwelling also promote predictable ice-free conditions in this area.

Fluctuating ice conditions around southwest Baffin Island would have biological ramifications in Frobisher Bay. For example, a greater extent of stable fast ice might increase ringed seal habitat by expanding the area suitable for making birthing dens. Especially severe ice conditions, however, might create ice too thick for breathing holes and result in reduced concentrations of sea mammals and reduced primary productivity (Stirling et al., 1981). The persistence of the floe edge in the outer bay during recent years suggests that Countess of Warwick Sound would be less affected than upper Frobisher Bay by these kinds of fluctuations. Changing concentrations of pack ice on the eastern margins of the polynya may affect the ranges of species associated with open water or mixed pack ice, such as walrus and bearded seal. The species may shift north or south in response to temperature and ice distribution changes.

Ringed seals are present year-round in outer Frobisher Bay and are associated with both open water and icebound conditions. They make their birthing lairs in the stable fast ice and tidal ridges of the Bay (Smith et al., 1991; Riewe,

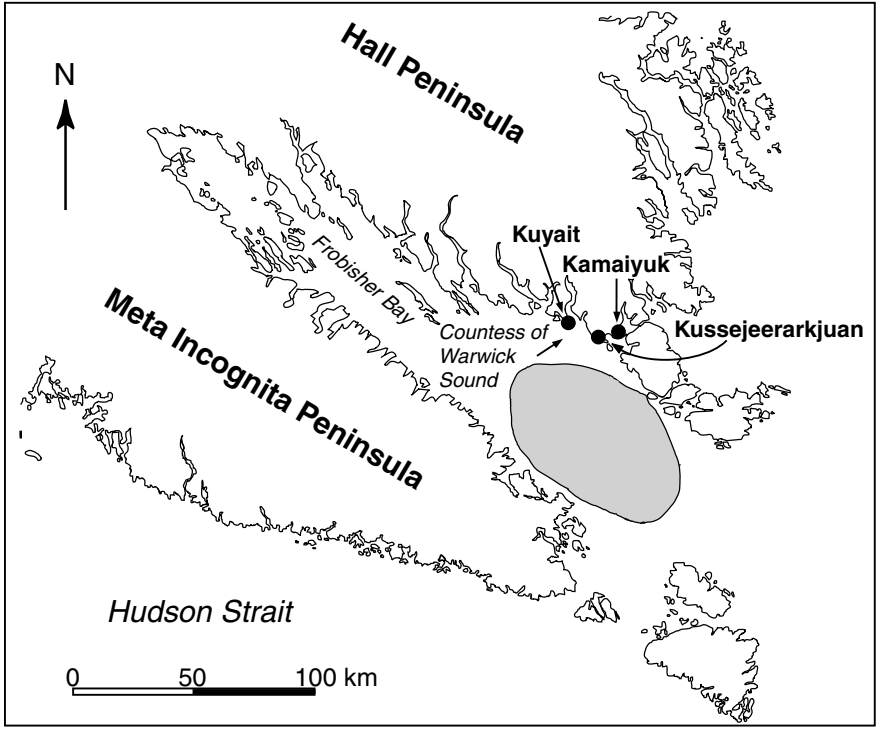

FIG. 4. Map of Frobisher Bay, Baffin Island. The shaded area indicates the approximate location of the outer bay polynya, which is limited by fast ice and shorelines to the north, west, and south, and by pack ice to the east.

1992). Migrating harp seals are present in the bay from breakup to freeze-up and are common in late summer and fall (Riewe, 1992). Currently, a small number of harbour seals are found in some of the inlets along and adjacent to Frobisher Bay, and they likely breed in the region (Riewe, 1992). Bearded seals are also present in the outer Bay yearround. They disperse in the pack ice during the winter and favour shallows around islands within the Bay in summer (Smith et al., 1979; Riewe, 1992). Walrus are found in outer Frobisher Bay primarily in the fall but may overwinter in ice-free areas as well (Riewe, 1992).

Excavations in the outer bay yielded a number of wellpreserved faunal collections (Henshaw, 1995, 1999a, b). Sea mammal remains dominate all these assemblages and include large numbers of small seals, bearded seals, and walrus. Caribou represent the major terrestrial prey species in these collections, but are of secondary importance in comparison to sea mammals, comprising approximately 4 to $25 \%$ of household assemblages (Henshaw, 1995).

NISP counts and percent frequencies of sea mammal specimens from these sites are presented by house and grouped by site in Table 4. As for the Eskimo Island analysis, the statistics presented here are derived from counts of identified cranial elements and humeri. While NISP counts for small seals previously reported by Henshaw (1995, 1999a) were derived from cranial elements and humeri, those for bearded seal and walrus were based on all skeletal elements. New NISP counts for the larger sea 
406 • J.M. WOOLLETT et al.

TABLE 4. Frequencies of sea mammal bones (NISP) in archaeological assemblages from outer Frobisher Bay, Baffin Island. \% NISP is given in parentheses.

\begin{tabular}{|c|c|c|c|c|c|c|c|c|c|c|}
\hline \multirow{2}{*}{$\begin{array}{l}\text { Kamaiyuk } 16 \text { th }-19 \text { th century } \\
\text { Ringed Seal }\end{array}$} & \multicolumn{2}{|c|}{ Site NISP } & \multicolumn{2}{|c|}{$\mathrm{H} 1$} & \multicolumn{2}{|c|}{$\mathrm{H} 2$} & \multicolumn{2}{|c|}{ H3 } & \multicolumn{2}{|c|}{$\mathrm{H} 4$} \\
\hline & 77 & $(70.0)$ & 13 & $(72.2)$ & 27 & (64.3) & 24 & $(75.0)$ & 13 & $(72.2)$ \\
\hline Bearded Seal & 7 & (6.4) & & & 5 & (11.9) & 2 & (6.3) & & \\
\hline Harbour Seal & 8 & $(7.3)$ & & & 6 & (14.3) & 2 & $(6.3)$ & & \\
\hline Harp Seal & 7 & $(6.4)$ & 1 & $(5.6)$ & 1 & $(2.4)$ & 2 & $(6.3)$ & 3 & (16.7) \\
\hline Walrus & 11 & $(10.0)$ & 4 & $(22.2)$ & 3 & $(7.1)$ & 2 & $(6.3)$ & 2 & $(11.1)$ \\
\hline Total NISP & 110 & & 18 & & 42 & & 32 & & 18 & \\
\hline Kuyait A.D. $1920-30$ & \multicolumn{2}{|c|}{ Site NISP } & \multicolumn{2}{|c|}{ H11 } & \multicolumn{2}{|c|}{$\mathrm{H} 12$} & \multicolumn{2}{|c|}{ H5 } & & \\
\hline Ringed Seal & 92 & $(69.2)$ & 36 & $(63.2)$ & 27 & (77.1) & 29 & $(70.7)$ & & \\
\hline Bearded Seal & 11 & (8.3) & 5 & (8.8) & 1 & (2.9) & 5 & (12.2) & & \\
\hline Harbour Seal & 9 & (6.8) & 4 & $(7.0)$ & 3 & (8.6) & 2 & (4.9) & & \\
\hline Harp Seal & 5 & $(3.8)$ & 1 & $(1.8)$ & 3 & $(8.6)$ & 1 & $(2.4)$ & & \\
\hline Walrus & 16 & $(12.0)$ & 11 & $(19.3)$ & 1 & $(2.9)$ & 4 & $(9.8)$ & & \\
\hline Total NISP & 133 & & 57 & & 35 & & 41 & & & \\
\hline Kussejeerarkjuan A.D. 1910-30 & \multicolumn{2}{|c|}{ Site NISP } & \multicolumn{2}{|c|}{$\mathrm{H} 2$} & \multicolumn{2}{|c|}{$\mathrm{H} 3$} & \multicolumn{2}{|c|}{ H6 } & & \\
\hline Ringed Seal & 91 & $(82.7)$ & 40 & $(95.2)$ & 30 & (71.4) & 21 & $(80.8)$ & & \\
\hline Bearded Seal & 8 & $(7.3)$ & & & 6 & (14.3) & 2 & (7.7) & & \\
\hline Harbour Seal & 5 & $(4.5)$ & 1 & $(2.4)$ & 4 & $(9.5)$ & & & & \\
\hline Harp Seal & 2 & (1.8) & & & 1 & $(2.4)$ & 1 & $(3.8)$ & & \\
\hline Walrus & 4 & (3.6) & 1 & $(2.4)$ & 1 & (2.4) & 2 & (7.7) & & \\
\hline Total NISP & 110 & & 42 & & 42 & & 26 & & & \\
\hline
\end{tabular}

mammals were calculated for the present study to make counting units more readily comparable. Those for bearded seals are derived from the same elements used for the small seal species. Walrus counts include crania and humeri but exclude small facio-maxillary fragments that inflate NISP counts. The bulk of these small fragments were likely produced in the process of ivory extraction. Because bone assemblages for some houses are small and many houses could be dated only within broad parameters, this study focuses on house assemblages grouped by site and date.

Ringed seals are the most common sea mammal in all these assemblages, comprising between $69 \%$ and $82 \%$ of the sea mammal specimens in the combined site assemblages, and are somewhat more common in the historic assemblages. Bearded seals, harp seals, and harbour seals are represented in approximately equivalent proportions, each ranging from about $2 \%$ to $8 \%$ of the site assemblages. Walrus ranged between $4 \%$ and $12 \%$ of the site NISP counts. Overall, these figures suggest a fair degree of consistency in hunting practices through time, with secondary emphasis placed on species that favour open water and pack ice conditions.

NISP ratios are presented in Table 5 to illustrate patterns in frequencies of these different species. Comparison of the ratios shows a striking degree of similarity between site assemblages. Relatively little ordinal-scale variability can be observed in the ringed seal to bearded seal NISP ratios, nor in ratios of ringed seal NISP to the combined NISP counts of other sea mammals associated with open water and pack ice conditions. Notably, there is little change in ratios for the grouped house assemblages of the Kamaiyuk and Kuyait sites, which are dated to the 16th-
19 th century and $1920-30$, respectively. Insofar as these three sites represent similar kinds of settlements with similar seasons of occupation, ordinal-level comparisons of NISP and ratio data suggest that Inuit in outer Frobisher Bay followed a largely consistent pattern of hunting sea mammals. This implies generally similar degrees of concentration on open water and fast ice environments. Yearto-year variability in hunting patterns attributable to sea ice conditions seems to average out, with little cumulative trend of change. The Kussejeerakjuan assemblages, dating from 1910-30, follow the same pattern as the other sites, but with ratios that demonstrate larger proportions of ringed seals.

Variability between households in NISP appears more marked within sites than it is between sites. Because the variability in these ratios stems from relatively minor changes in \%NISP counts of rather small assemblages, the differences in ratios may be of minor significance. Significant outlier assemblages come from House 12 at Kuyait and House 2 at Kussejeerarkjuan, which have exceptionally high proportions of ringed seals. The differences between roughly contemporaneous house assemblages at Kuyait and Kussejeerarkjuan may also be due to variability in annual ice conditions associated with short-term household occupations. Years with more extensive fast ice and delayed spring breakup would tend to exclude some seal species from the region and encourage hunting of ringed seals on the fast ice. Open water hunting would then have been directed toward subadult ringed seals rather than bearded seals or walrus, as suggested by the proportions of these species in the Kuyait House 12 and Kussejeerarkjuan House 2 assemblages. As recent sea ice 
TABLE 5. Ratios of sea mammal NISP counts for archaeological assemblages from outer Frobisher Bay, Baffin Island.

\begin{tabular}{|c|c|c|c|c|c|}
\hline Kamaiyuk Ratios & Total Site & $\mathrm{H} 1$ & $\mathrm{H} 2$ & $\mathrm{H} 3$ & $\mathrm{H} 4$ \\
\hline Ringed Seal/Bearded Seal NISP & 11.00 & & 5.40 & 12.00 & \\
\hline Ringed Seal/Walrus NISP & 7.00 & 3.25 & 9.00 & 12.00 & 6.50 \\
\hline Ringed Seal/Bearded Seal and Walrus NISP & 4.28 & 3.25 & 3.38 & 6.00 & 6.50 \\
\hline Ringed Seal /All other species NISP & 2.33 & 2.60 & 1.80 & 3.00 & 2.60 \\
\hline Kuyait Ratios & Total Site & H11 & $\mathrm{H} 12$ & H5 & \\
\hline Ringed Seal/Bearded Seal NISP & 8.36 & 7.20 & 27.00 & 5.80 & \\
\hline Ringed Seal/Walrus NISP & 5.75 & 3.27 & 27.00 & 7.25 & \\
\hline Ringed Seal/Bearded Seal and Walrus NISP & 3.41 & 2.25 & 13.50 & 2.50 & \\
\hline Ringed Seal /All other species NISP & 2.24 & 1.71 & 3.38 & 2.42 & \\
\hline Kussejeerarkjuan Ratios & Total Site & $\mathrm{H} 2$ & $\mathrm{H} 3$ & H6 & \\
\hline Ringed Seal/Bearded Seal NISP & 11.38 & & 5.00 & 10.50 & \\
\hline Ringed Seal/Walrus NISP & 22.75 & 40.00 & 30.00 & 10.50 & \\
\hline Ringed Seal/Bearded Seal and Walrus NISP & 7.58 & 40.00 & 4.29 & 5.25 & \\
\hline Ringed Seal /All other species NISP & 4.79 & 20.00 & 2.50 & 4.20 & \\
\hline
\end{tabular}

models show, Kuyait and Kussejeerarkjuan are more distant from the floe edge than Kamaiyuk (Henshaw, 1995, 1999b). Therefore, sea ice changes would likely be more strongly felt by people living at these sites, whose travel time to the floe edge would increase in years of particularly extensive fast ice formation (Henshaw, 1999b, 2000).

Studies of dental annuli in seal teeth provide additional information about seal hunting activities (for more complete discussions, see Henshaw, 1995, 1999b). A small majority of the ringed seals at Kussejeerarkjuan were immature individuals, while mature individuals were more common in the assemblages from Kuyait and Kamaiyuk. A single mature ringed seal was attributed a summer death. Teeth from immature individuals indicated almost equal proportions of winter/spring and summer/fall seasons of death. One yearling specimen from Kussejeerarkjuan was killed in spring or summer. Overall, the dental annuli analyses suggest that ringed seals were hunted through the winter, spring, and summer, implying the use of open water, floe edge, and fast ice environments. It is likely that numbers of mature seals and pups were taken in winter and spring in their fast ice habitat. The floe edge associated with the polynya was also important because a substantial portion of immature ringed seals, which are typically excluded from fast ice (Smith, 1973, 1987), were taken throughout the winter and spring. The other species present that are associated with open water and the floe edge, such as walrus, bearded seal, and possibly harbour seal, further emphasize the importance of the floe edge environment (Henshaw, 1995).

The picture of hunting in outer Frobisher Bay portrayed by these archaeological data is one of remarkable consistency through time, suggesting that historic Inuit hunters made effective use of the outer bay environment in generally similar fashions. Because the occupations of the outer Frobisher Bay sites span periods of both heavy and light sea ice concentration, as defined by the PIC sodium record, it seems likely that the polynya persisted despite changing climate conditions. GIS-based studies of recent ice dynamics further reinforce this interpretation (Henshaw, 1995, 1999b). As well, the redundancy of the seal ratios may suggest stable sea mammal populations in this region. The apparently predictable nature of the outer bay would have made it a reliable location for winter and spring sea mammal hunting. The degree of stability demonstrated by this polynya contrasts with the marked variability shown for the Narrows Strait in Labrador. Their simultaneous differences strongly suggest that not all polynyas are similar environments, and that climate change trends over large regions may have variable local effects. Small polynyas or those that occur irregularly seem to be more sensitive indicators of the biological effects of climate change.

\section{OSTEOMETRIC COMPARISON OF ARCHAEOLOGICAL RINGED SEALS IN FROBISHER BAY AND THE NARROWS}

Growth patterns of ringed seals may be examined through osteometric comparisons of particular skeletal elements. This study assumes that the size of adult individuals reflects infant growth and that the size of individual skeletal elements varies with respect to total body size. Measurements were taken according to procedures defined by Spiess and Hedden (1983) for use with archaeological specimens. The measurements used include a) the length of the mandibular post-canine tooth row, measured at its alvaeolar margins, and b) the greatest thickness of the mandibular ramus (bucco-lingual) inferior to the fifth post-canine. Mandibles were used for comparison because they are dense, durable, and easy to identify, and because measurements for ringed seal specimens were available for both the Frobisher Bay sites and the Eskimo Island sites, as well as for a small sample of modern specimens collected in Okak Bay, Labrador. Foetal, neonate, and infant specimens were excluded from this study. A scatter 
plot graphing tooth row length versus alvaeolar width of these specimens is presented in Figure 5.

Despite the small size of the samples considered here, two interesting features are illustrated in this scatterplot. The distribution is divided into two general groups. The largest specimens are almost uniformly those of the protohistoric and historic sites from Frobisher Bay, while the archaeological and modern Labrador specimens are relatively small, in terms of both tooth row length and robusticity. The distributions of mandible measurements for the Labrador collections have a larger degree of overlap. The longest tooth rows were found in the Eskimo Island 2 and 3 collections and in the modern sample, while the most robust mandibles were found in the Eskimo Island 2 and 3 collections. The set of smaller mandibles included some specimens from every collection and all the specimens from Eskimo Island 1.

The Frobisher Bay specimens might be expected to be larger if ringed seal growth is closely related to the stability of ice cover. Fast ice is present for more of the year in Frobisher Bay than in Labrador, forming in late October and clearing in mid June to July (Crane, 1978: Fig. 3). The complex and deeply indented coastline of Frobisher Bay and its islands also make for very stable, well-sheltered, and extensive fast ice conditions in this region. This suggests that there would be an ample and highly reliable area of ringed seal pupping habitat adjacent to outer Frobisher Bay in most environmental conditions. The more favorable ringed seal habitat may result in higher infant growth rates and larger adults. Also worthy of notice is that the ringed seal specimens from protohistoric sites in outer Frobisher Bay fell within the size range of the 20th-century archaeological specimens, although at the lower end of this range. It will be interesting to observe whether future zooarchaeological research can show clearer morphometric distinctions between ringed seals of this region, or whether growth patterns were similar through time.

The smaller size of almost all the Labrador specimens, in terms of absolute length and especially robusticity, suggests that Labrador's shorter ice season (December to June) and less extensive coastal ice may provide a less favorable pupping environment for ringed seals than does Frobisher Bay. This difference may be most strongly manifest in spring, as the breakup of fast ice comes closer upon ringed seal weaning dates in Labrador than it does in Baffin Island.

A broad range of size for ringed seals is indicated for the Labrador collections, with considerable overlap of individuals in different time periods. The small group of modern adults from Okak Bay, an area of relatively extensive and stable fast ice, was rather large in terms of tooth row length, though much less robust than the Frobisher Bay specimens. Both large and small individuals are represented in the 17th- and 19th-century assemblages, though even the largest of these were smaller than almost all the Frobisher Bay specimens. The few 18th-century specimens that could be measured are among the smallest in the scatter plot.
Assuming the reliability of this sample, the overlap of size ranges for ringed seals in the various time periods suggests that, in all periods, hunting efforts in the Narrows were directed towards both larger, mature seals and smaller or subadult seals. These categories of individuals are generally associated in winter with fast ice and pack ice, respectively. The overlap of size ranges may also indicate a relatively high proportion of small, slow-growing seals in all periods, especially the 18th century. The uniformly smaller size of all the 18th-century ringed seals represented is consistent with the proposition that ice conditions were relatively moderate in the Hamilton Inlet region, insofar as the size of ringed seals is correlated to ice conditions. The earlier spring breakups suggested by the proxy sea ice records would likely have affected parental attention, weaning times, and infant survivorship. Osteometric studies may present a useful and practical method of assessing variability in past growth rates in archaeological populations. The real significance of the size differences noted here is difficult to assess and requires further investigation with modern control populations and larger archaeological collections.

\section{CONCLUSIONS}

In this study, we have attempted to explore the application of some zooarchaeological methods to palaeoenvironmental reconstructions and to research concerning biological responses to Arctic environmental change. Specifically, we have examined means by which historical sea ice changes in particular regions and their accompanying biological changes might be identified through changes in archaeological faunas. Because animal bones are common and well preserved in many Arctic archaeological sites, the archaeological record is a natural place to look for information about historical animal populations. While they are not direct records of former living communities, archaeological faunas are proxies for the animal populations hunted and used by people in the past. Zooarchaeological studies can be used to examine the nature of resources exploited by past peoples and the effectiveness of their different hunting techniques, the variables that pertain to the nature of resources available in the past, and changes in palaeoenvironments. Most importantly, zooarchaeology can also provide data about the ecological history of certain regions, placing particular species and age classes in these localities in particular seasons. Zooarchaeological data can therefore be a supplement to proxy environmental records and to the traditional ecological knowledge data sources increasingly used in ecological studies today.

Several methods can be used together to facilitate examination of biological responses to changing sea ice conditions. Zooarchaeological studies may focus on indicator species, such as ringed seals, that have specialized habitat requirements. Particular landscape and seascape features (such as polynyas) that are defined by sea ice 


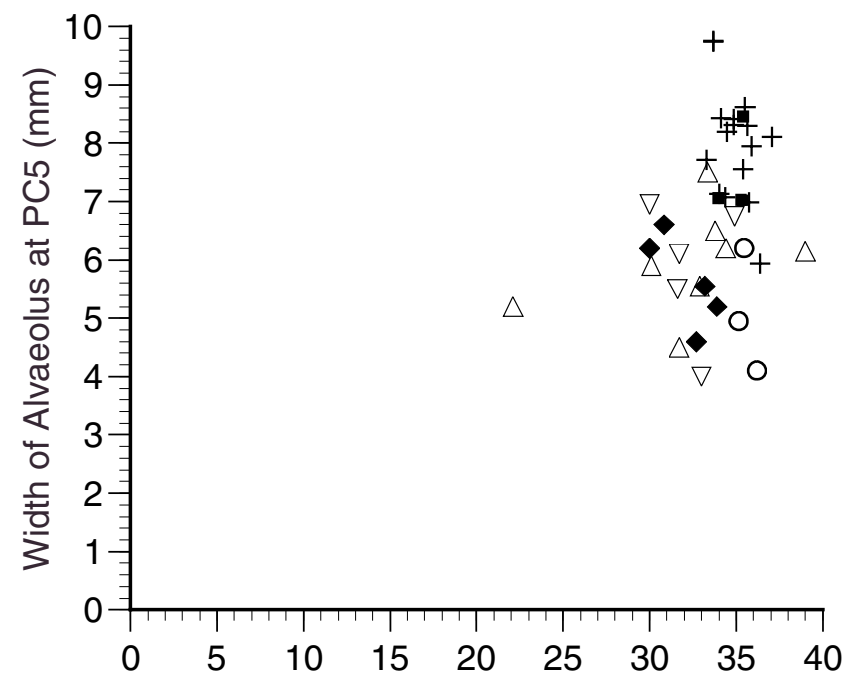

Length of Post-canine Tooth row ( $\mathrm{mm}$ )

$\begin{array}{llll}+ \text { Frobisher Bay Hist. Inuit } & \bullet & \text { El 1 18th C. } \\ -\quad \text { Frobisher Bay 1400-1700 } & \triangle & \text { El } 2 \text { 19th C. } \\ \nabla & \text { El 3 17th C. } & \circ & \text { Okak Bay 1990s }\end{array}$

FIG. 5. Scatterplot of toothrow length and width measurements of ringed seal mandibles from archaeological and modern collections.

conditions and attract diverse animal populations may be especially effective locations to monitor environmental changes. Polynyas also draw human settlement, and many are associated with long-term occupation and extensive archaeological records (Schledermann, 1980). Zooarchaeological studies must consider both species abundance data and additional life history studies (including the attributes of seasonality, age of death, and growth patterns for hunted indicator species) over regional scales. These archaeological data also require well-defined chronological and taphonomic controls to ensure comparability. Finally, multiple independent lines of palaeoenvironmental evidence are needed to reconstruct complex ecological phenomena. Recent glaciochemical research projects provide the background of excellent, high-resolution data focused on pertinent variables that is necessary to link archaeology with environmental features.

Hunting patterns, seasonality, and various proxy sea ice records together provide one basis for long-term studies of polynya formation and biological response in the Labrador and Baffin Island regions. We have demonstrated that some variability of hunting practices can be linked to sea ice changes. However, the topic begs for continued research. These examples inform both reconstructions of ecological change and archaeological studies of culture change.

The frequencies of ringed seals and harbour seals in archaeological deposits in the Narrows Strait of Hamilton Inlet are effective aids in defining the fluctuating southern edge of Arctic climatic influences in Labrador. Winter and spring hunting patterns here showed a striking correspondence to sea ice records, suggesting that phases of apparent expansion of harbour seals into, and their exclusion from, winter habitat in the Narrows were driven by variable sea ice trends.

The example drawn from Frobisher Bay presents a very different case. Here, hunting around a large, recurrent polynya was shown to have been remarkably consistent through time, and this consistency is likely due to the stability of both the polynya itself and its marine mammal populations. The methods used here are therefore insensitive environmental indicators in some environments. For this reason, further research should concentrate on smaller and less predictable intermittent polynyas to document non-extreme scales of variability. Additional research considering the relationship between pup growth and climate, as well as methods to identify growth rates in archaeological materials, is also needed. Furthermore, improved standards for identifying seal species on a broader range of elements, morphologically or osteometrically, would increase the number of archaeological samples that might contribute to biogeographic studies.

Both examples also point out the need to remember the culturally situated nature of economic decision making in archaeological reconstructions. Changing economic priorities accompanying culture contact play a role in the hunting patterns demonstrated in all the sites considered here. Opportunities to trade seal skins or other seal products, as well as the adoption of new extractive technologies, such as firearms and seal nets, all played roles in these economies, especially after the turn of the 19th century. Integration of zooarchaeological data with technological studies and oral histories concerning use of specific polynyas, as well as with sea ice records, is necessary to make effective use of the biogeographic potential of this information.

None of the methods considered here are particularly new to Arctic archaeology. However, they have been systematically applied only to a relatively small number of Neoeskimo or Palaeoeskimo archaeological sites, suggesting that there is much more that both archaeologists and palaeoenvironmental researchers might learn from them. Archaeological seal data might not yet be able to provide "stand-alone" proxies for sea ice in their own right; however, as a part of a set of convergent data sources, they can make important contributions to the history of important seascape features such as polynyas.

\section{ACKNOWLEDGEMENTS}

The authors thank Douglas Stenton and three anonymous readers for their careful reviews of earlier versions of this paper and for their constructive criticism. This study relies on Nancy Grumet's key research on the Penny Ice Cap proxy ice record, and we thank her for her work. As well, Michael Hammill and Jean-François Gosselin contributed advice and guidance. Thanks 